\title{
Effects of Handling and Physical Restraint on Rectal Temperature, Cortisol, Glucose and Leucocyte Counts in the Silver Fox (Vulpes vulpes)
}

\author{
By R. Oppermann Moe ${ }^{1}$ and M. Bakken ${ }^{2}$
}

${ }^{1}$ Norwegian College of Veterinary Medicine, Research Farm, Heggedal, and ${ }^{2}$ Agricultural University of Norway, Department of Animal Science, Ås, Norway.

\begin{abstract}
Oppermann Moe, R. and M. Bakken: Effects of handling and physical restraint on rectal temperature, cortisol, glucose and leucocyte counts in the silver fox (Vulpes vulpes). Acta vet. scand. 1997, 38, 29-39. - The present paper describes the effects of handling and one hour of physical restraint on rectal temperature $\left(\mathrm{T}_{\text {rec }}\right)$, plasma cortisol, plasma glucose and leucocyte counts in six 8-months old silver fox vixens (Vulpes vulpes). Mean $\mathrm{T}_{\text {rec }}$ in silver foxes $5 \mathrm{~min}$ after capture was $40.1^{\circ} \mathrm{C}$ and increased during restraint, showing a maximum of $40.8^{\circ} \mathrm{C}$ at 30 min thereafter. Supplementary, deep body temperature $\left(\mathrm{T}_{\mathrm{b}}\right)$ was recorded with surgically implanted biotelemetry devices in 6 adult silver fox vixens kept isolated from environmental disturbances in a barn. Mean $\mathrm{T}_{\mathrm{b}}$ in these foxes ranged between $38.0-38.4^{\circ} \mathrm{C}$, showing a diurnal variation and being at the lowest between 0700-1600 hour. When a person approached a fox and was present for $5 \mathrm{~min}, \mathrm{~T}_{\mathrm{b}}$ increased rapidly. The results indicated that a stress-induced hyperthermia (SIH) was evoked rapidly within the first registration at $5 \mathrm{~min}$ after capture, and that this response continued during one hour of physical restraint. Plasma glucose and plasma cortisol levels increased during one hour of physical restraint, whereas numbers of lymphocytes, total white blood cell counts, and total granulocytes decreased. Furthermore, previously reported base levels of plasma cortisol and plasma glucose were exceeded. The results indicate that the hypothalamic-pituitary-adrenal (HPA) axis and the sympathoadrenal medullary (SAM) system were activated within 5 min of handling and restraint. Furthermore, hyperthermia is a promising indicator of acute stress in silver foxes.
\end{abstract}

fur-bearing animals; granulocytes; HPA axis; lymphocytes; radio telemetry; SAM system;stress; welfare; white blood cells.

\section{Introduction}

The welfare of farmed fur-bearing animals such as the silver fox is frequently questioned. It is generally accepted that the presence or absence of stress provides a meaningful approach to measure animal welfare on a scientific basis (Moberg 1985). According to Chrousos et al. (1988) stress is 'the recognition by the body of a stressor and therefore the state of threatened homeostasis; stressors are threats against ho- meostasis; and adaptive responses are the body's attempt to counteract the stressor and reestablish homeostasis'. As a contribution to the ongoing work aiming to increase welfare in farmed silver foxes, species-specific indicators of stress are currently investigated. Previous investigations in silver foxes have focused on chronic effects of adverse environmental stimuli on alterations of plasma cortisol levels and 
leucocyte counts in connection with behavioural studies (Jeppesen \& Pedersen 1991). Furthermore, frequently experienced acute environmental stressors may in the long term endanger welfare (Moberg 1985). However, the recognition of acute environmental stressors, as well as the measurement of acute stress responses, may be obscured by the fact that the stress associated with blood sampling may mask effects of actual stressors under investigation (Moe \& Bakken 1996).

Numerous studies in laboratory rodents (Kluger et al. 1987, Borsini et al. 1989, Lecci et al. 1990, Briese \& Cabanac 1991, Cabanac \& Briese 1991, Groenink et al. 1994, Zethof et al. 1994) showed that various stressors such as handling, restraint or the anticipation of an unpleasant event result in increased body temperature, termed stress-induced hyperthermia (SIH). Our group has initiated studies on SIH as a possible physiological indicator of acute stress in silver foxes.

The present study aimed to investigate how SIH is related to the activation of the hypothalamicpituitary-adrenal (HPA) axis and the sympathoadrenal medullary (SAM) system during stress induced by handling and physical restraint. Rectal temperature $\left(\mathrm{T}_{\text {rec }}\right)$ as a measurment of SIH; plasma cortisol, used as an indicator of HPA axis activity; plasma glucose, as an indicator of SAM system activity (Smythe et al. 1989) and various leucocytes, some of them previously used as indicators of stress in silver foxes (Jeppesen \& Pedersen 1991, Moe \& Bakken 1996) were investigated during one hour of physical restraint. As supplementary observations, the paper presents observations of deep body temperature $\left(T_{b}\right)$ from unrestrained and undisturbed foxes and gives one example of increases in $T_{b}$ during the presence of a person recorded with surgically implanted transmitters in other silver foxes.

\section{Materials and methods}

\section{Animals and housing conditions}

All silver foxes used in the experiment were housed at the Research Farm at the Agricultural University of Norway. For the restraint experiment, six 8-months old female silver foxes were kept individually in traditional wire-netting cages for foxes located in a traditional fur shed under outdoor conditions.

For supplementary observations, 6 adult silver fox vixens equipped with surgically implanted radio transmitters (for a detailed description of the surgical procedure, see (Moe et al. 1995) were kept individually in similar cages, but these were located in an empty barn isolated from external disturbances with the exception of daily feeding routines at 1700 hours. In order to avoid direct social contact between the foxes, an empty netting cage was placed in between the individuals. Furthermore, one silver fox vixen, also equipped with a similar transmitter and kept in a similar cage sheltered from environmental disturbances located in another barn, was included in the study.

The experiment was carried out during November.

\section{Experimental procedures}

For the restraint experiment, 3 foxes were consecutively captured and lifted out of the cage at 5 min intervals starting at 0900 hours. They were consecutively carried indoors to the site of the experiment, and physically restrained for one hour on a stockmans lap (Fig. 1). The time elapsed between capture and the first registration was approximately $5 \mathrm{~min}$. The ambient temperature in the room was approximately $15^{\circ} \mathrm{C}$. It was observed when the foxes initiated panting. After the experiment, the foxes were immediately put back into their home cage. Starting at 1100 hours, the other 3 foxes received a similar treatment.

During physical restraint, i.e. at $0,10,20,30$ 
and 55 min after entering the site of the experiment, 5 blood samples were drawn from the cephalic vein. Previous observations with transmitter implants revealed that $T_{b}$ begins to increase immediately after onset of handling or physical restraint, and that $T_{b}$ and $T_{\text {rec }}$ were of $a$ similar elevated magnitude when the foxes were handled (Moe \& Bakken, in press; Moe, unpublished observations). Therefore, the measurement of $T_{\text {rec }}$ served as the stressor that elicited $\mathrm{SIH}$ in the present study. $\mathrm{T}_{\text {rec }}$ was measured in all foxes using a standard commercially available digital thermometer inserted approximately $4 \mathrm{~cm}$ into the rectum. The accuracy of the thermometer was stated to be $\pm 0.1^{\circ} \mathrm{C}$, and $\mathrm{T}_{\text {rec }}$ was recorded when the reading was stable, i.e. after approximately one minute. Each blood sample consisted of a total of $5 \mathrm{ml}$, i.e. $1 \mathrm{ml}$ into glass tubes coated with EDTA $\left(\mathrm{K}_{3}\right)$ for the leucocyte counts, and $4 \mathrm{ml}$ into heparinized glass tubes for cortisol and glucose measurement. The latter blood samples were centrifuged for 10 min at 3000 RPM during the course of sampling, and plasma was stored in plastic tubes and assayed within $3 \mathrm{~h}$.

The analyses were performed at the Central Laboratory for Clinical Chemistry at the Norwegian College of Veterinary Medicine. Lymphocytes, total granulocytes, and total white blood cells (WBC) were counted automatically within $3 \mathrm{~h}$ after sampling using a Technicon $\mathrm{H}^{*}$ automatic analyzer (Technicon $\mathrm{H}^{* \mathrm{TM}}$ Systems). The method has been validated for dog blood (Control: TESTpoint ${ }^{\mathrm{TM}}$ Hematology Control N) and has previously been used for silver fox blood (Moe et al. 1995, Moe \& Bakken 1996). Cortisol concentrations were assessed by a competitive immunoassay technique (Amerlite Cortisol Assay). This assay had a detection limit of 3 $\mathrm{nmol} / \mathrm{l}$, and the total coefficient of variation was $5.2 \%$. The method has previously been used in silver foxes (Jeppesen \& Pedersen 1991), but has not been validatad for this species. Glucose

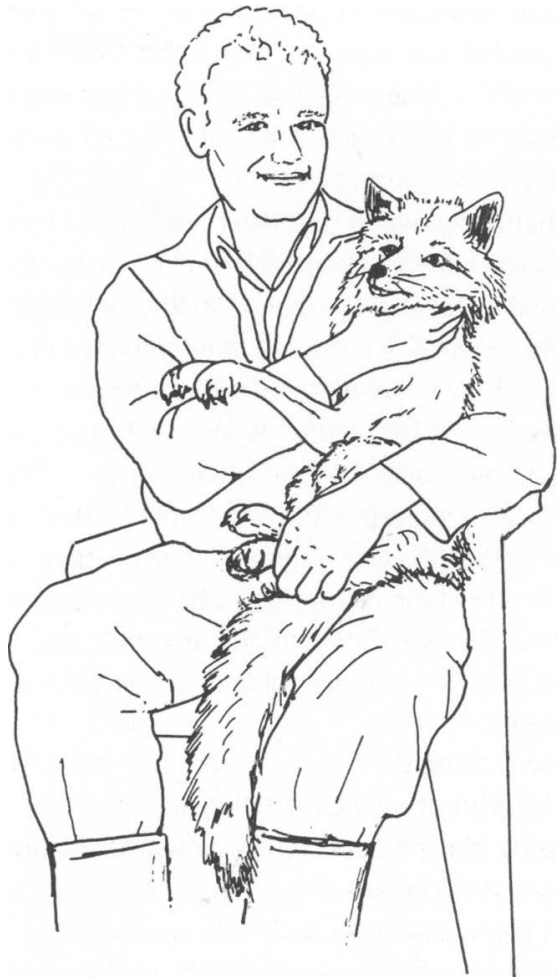

Figure 1. Physical restraint of silver foxes during the present study. Blood samples were drawn from the cephalic vein.

concentrations were measured photometrically with a Technicon Axon ${ }^{\mathrm{TM}}$ automatic analyzer. The average sensitivity of the method was $0.000018 \mathrm{~A}$ per $\mathrm{mmol} / \mathrm{l}$, and the total coefficient of variation was $2.4 \%$.

To describe a diurnal variation, $\mathrm{T}_{\mathrm{b}}$ was measured using surgically implanted battery-operated biotelemetry devices (TA10CTA-D70L60, MiniMitter, Inc., Sunriver, OR, USA) and recorded every $4.5 \mathrm{~min}$ during $24 \mathrm{~h}$ for 5 consecutive days. The accuracy of the recording was stated to be $\pm 0.1^{\circ} \mathrm{C}$. For supplemantary information, see Dataquest III User Manual (1991). 
$\mathrm{T}_{\mathrm{b}}$ and heart rate was continously recorded in one silver fox with an implanted transmitter. This fox was approached by a person that remained in the front of the cage for $5 \mathrm{~min}$ and then left the room.

Statistical analyses and tests were made by using General Linear Models (GLM) in the Statistical Analysis System Institute programme package (SAS, 1986). For the restrained foxes, all data on dependent variables (cortisol, glucose, $T_{\text {rec}}$, WBC, lymphocytes, and granulocytes) are presented as least square means \pm SE in a model with individual and minutes after capture as independent variables. The average $T_{b} \pm$ SD every hour during day and night are presented. $T_{b}$ and heart in the fox that was approached by a person was not statistically analysed.

\section{Results}

Results are presented in Figs. 2-6. Mean initial $\mathrm{T}_{\text {rec }}$ in the 6 handled and restrained foxes was $40.1^{\circ} \mathrm{C} \pm 0.1$ (SE) and increased during restraint $(F=9.33, p<0.01$; Fig. 2). Highest mean $\mathrm{T}_{\text {rec }}$ was $40.8^{\circ} \mathrm{C} \pm 0.1$ (SE) at $30 \mathrm{~min}$ after entering the site of the experiment. Fig. 3 shows the diurnal variation of $T_{b}$ in the 6 undisturbed foxes measured with transmitter implants, ranging between on average $38.0-38.4^{\circ} \mathrm{C} \pm 0.3$ (SD), being at the lowest between 0700 hours1600 hours. Fig. 4 shows $T_{b}$ and heart rate in one fox in response to the presence of a person in the front of the cage for $5 \mathrm{~min}$.

There was a significant increase in plasma cortisol during one hour of restraint $(\mathrm{F}=194.56$, $\mathrm{p}<0.0001$; Fig. 5). Plasma glucose levels increased $(F=18.68, p<0.001$; Fig. 5), whereas WBC, lymphocytes and total granulocytes decreased during restraint $(\mathrm{F}=74.57, \mathrm{p}<0.0001$; $\mathrm{F}=31.39, \mathrm{p}<0.0001 ;$ and $\mathrm{F}=64.91, \mathrm{p}<0.0001$, respectively (Fig. 6).

The foxes started to pant between 15-30 min after capture.

\section{Discussion}

$\mathrm{T}_{\text {rec }}$ in all restrained foxes was substantially elevated when compared with $\mathrm{T}_{\mathrm{b}}$ of unrestrained animals. Furthermore, $T_{\text {rec }}$ continued to increase the initial $30 \mathrm{~min}$ of restraint. In the light of our previous studies, where $T_{b}$ and $T_{\text {rec }}$ were similarly elevated when the foxes were handled (Moe \& Bakken, in press, Moe, unpublished observations), the elevated $\mathrm{T}_{\text {rec }}$ indicates that the stress induced by capture and handling evoked a SIH within the first registration, and that the SIH response continued during restraint. This assumption was supported by the observation that even the mere presence of a person rapidly evoked a SIH (Fig. 4). The experimental design did not allow for a definition of the excact magnitude of SIH. Our previous experiments reveiled that measuring $\mathrm{T}_{\text {rec }}$ with few, if any, exceptions immediately induces a substantial rise in body temperature. Even in mice, $\mathrm{T}_{\text {rec }}$ has been reported to increase up to $1.9^{\circ} \mathrm{C}$ owing to handling stress (Zethof et al. 1994).

It has to be emphasized that $\mathrm{T}_{\text {rec }}$ in the present study was elevated compared with most of our studies in adult silver foxes. In these studies, $\mathrm{T}_{\text {rec }}$ was $39.4-39.7^{\circ} \mathrm{C}$ immediately after capture (Moe \& Bakken, in press, Moe \& Bakken, unpublished observations). As the foxes used for the present study were only 8 months old, the findings may reflect age differences in the SIH response, or in the basal $\mathrm{T}_{\mathrm{b}}$. At present, we do not have studies on $T_{b}$ recorded with transmitter implants in young foxes that may elucidate this further. However, $\mathrm{T}_{\text {rec }}$ up to $42^{\circ} \mathrm{C}$ has been observed in some adult silver foxes immediately after capture and during handling and physical restraint, which may indicate individual differences in the SIH response (Moe \& Bakken unpublished observations). The magnitude of $\mathrm{T}_{\text {rec }}$ may have been influenced by the fact that the experiment was carried out indoors, and that the foxes had a winter fur and were adapted to outdoor conditions. However, 


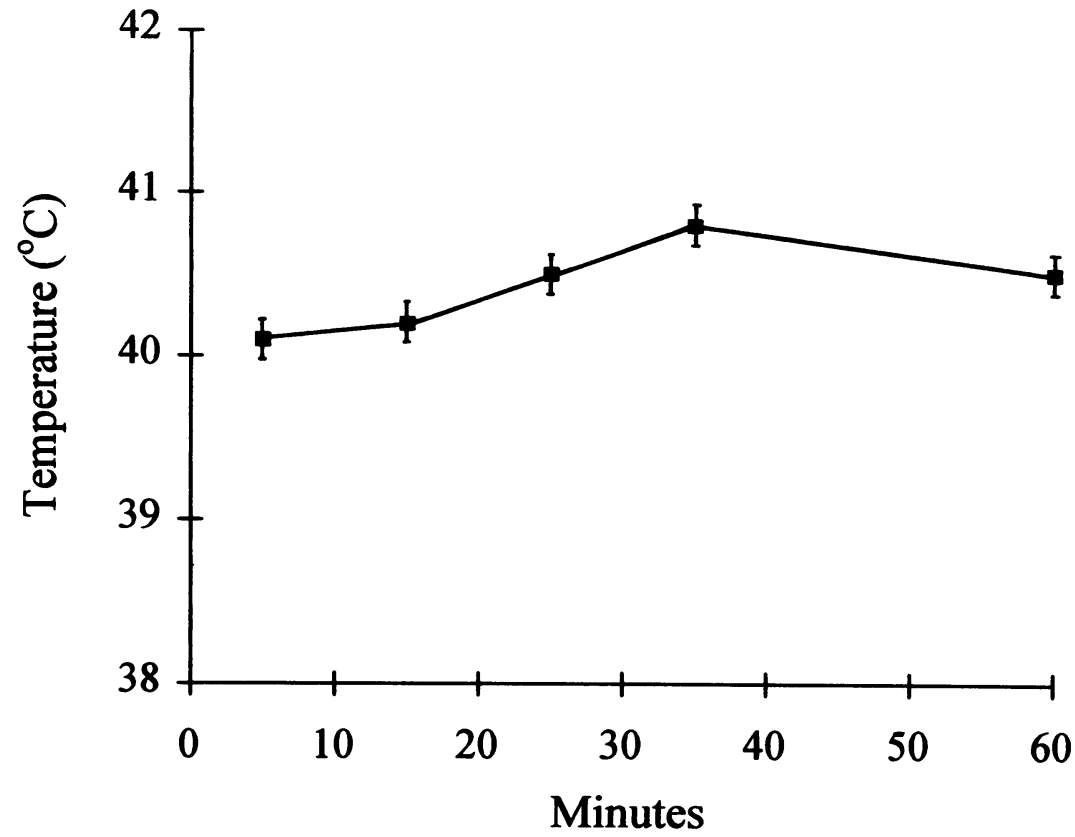

Figure 2. Mean rectal temperature $( \pm \mathrm{SE})$ in 6 silver foxes during one hour of physical restraint. The time elapsed between capture and the first registration was approcimately $5 \mathrm{~min}$, indicated by the open space between 0-5 min.

similar $\mathrm{T}_{\text {rec }}$ has been observed in clinically healthy silver foxes exposed to handling and restraint under outdoor conditions during the winter (Moe unpublished observations). Furthermore, the magnitude of SIH in rats was not affetced by different ambient temperatures (Long et al. 1990a). Thus, the elevated $\mathrm{T}_{\text {rec }}$ may probably not be ascribed to environmental temperature or to the winter fur coat alone. As panting was initiated after approximately 15-30 min, it may be speculated that SIH in silver foxes is due to a regulated shift of the thermoregulatory set-point, as has been suggested in laboratory rodents (Kluger et al. 1987, Briese \& Cabanac 1991).

SIH in silver foxes may be elicited by the mere presence of man (Fig. 4). Since the foxes in the present study were captured consecutively, it is possible that SIH already was evoked within capture and then continued to increase during restraint. It has been suggested that SIH may be elicited in response of the anticipation of a known or unknown unpleasant event, indicating that SIH may reflect a state of anticipatory anxiety (Lecci et al. 1990). Since farmed silver foxes generally fear man (Pedersen 1994), it is possible that SIH may reflect similar mechanisms in this species. A contribution of fear or anxiety pathways related to the development of $\mathrm{SIH}$ in silver foxes will be a focus of our subsequent studies.

As the foxes did not show strong active flight responses during capture, the magnitude of $\mathrm{T}_{\text {rec }}$ was probably not solely a result of increased physical activity. Other studies showed a lack of correlation between increased physical activity and SIH in laboratory rodents (Kluger et al. 1987, Borsini et al. 1989, Long et al. 1990b). 


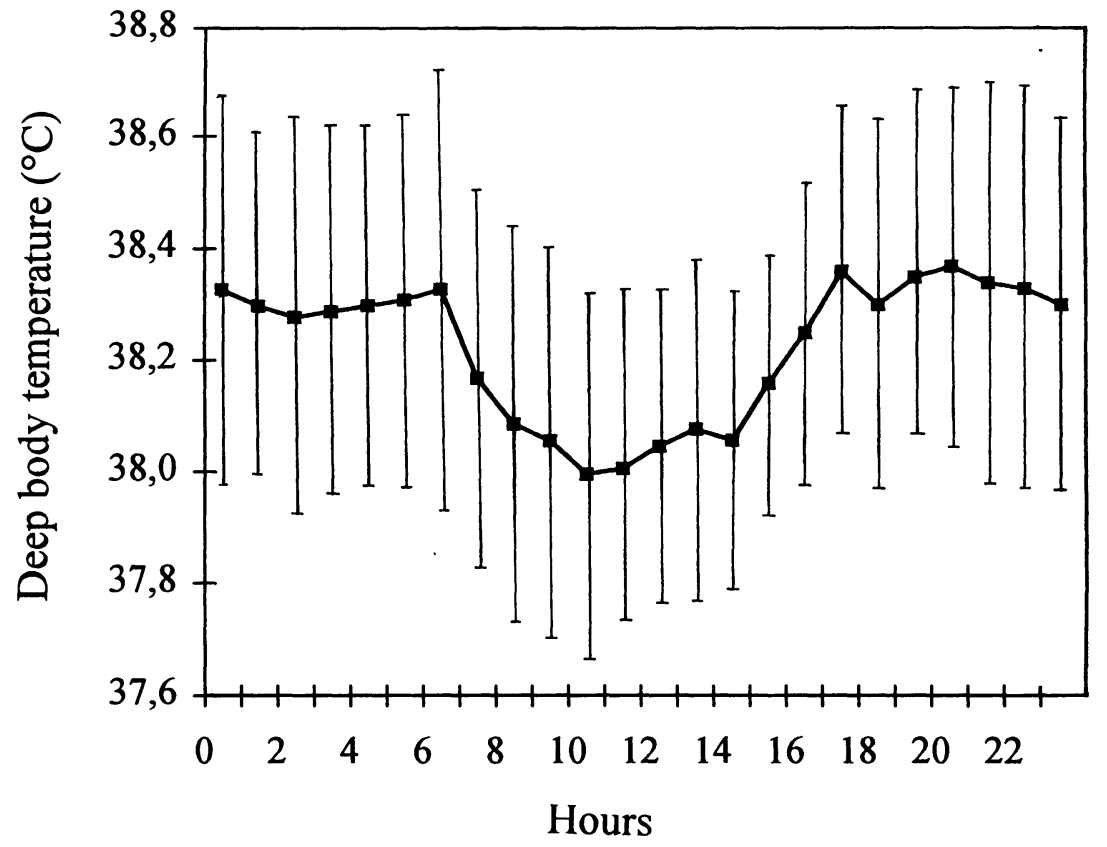

Figure 3. Diurnal variation of mean deep body temperature ( \pm SD) measured in 6 silver foxes with implanted radio telemetry devices, based on measurements every 4.5 min during 5 days. These foxes were kept isolated from external disturbances except of daily feeding at 1700 hours.

The present study demonstrates that the HPA axis, indicated by increasing plasma cortisol levels during handling and one hour of physical restraint, was activated. This finding supports previous observations on effects of handling in this species (Moe \& Bakken 1996). The initial levels substantially exceeded base levels reported from Danish studies using a similar cortisol assay (Jeppesen \& Pedersen 1991). As plasma cortisol is reported to increase approximately 2.5 min after onset of capture and sampling in silver foxes (Jeppesen \& Pedersen 1991), the initial levels of the present study probably reflected an activation of the HPA axis within the first registration at $5 \mathrm{~min}$ after capture. In agreement with this assumption, the cortisol levels measured initially in the present study were within the range of cortisol levels measured in adult silver fox vixens after $5 \mathrm{~min}$ of handling and physical restraint when assessed by a radioimmunoassay technique that had been validated for silver foxes (Moe \& Bak$k e n$, in press). Thus, the observed cortisol levels in the present study may reflect true levels. The number of circulating leucocytes decreased during one hour of restraint and indicated an activation of the HPA axis (see Madden \& Felten 1995). Rapid alterations of leucocyte counts during handling procedures as well as the range of lymphocyte and WBC are in agreement with previous studies using a similar automatical counting method (Moe et al. 1995, Moe \& Bakken 1996). This method has not yet been validated for silver foxes. However, the initial WBC was within the range of previously reported base levels for this species (Wenzel \& Berestov 1986), and the relative frequency of lymphocytes and granulocytes was 

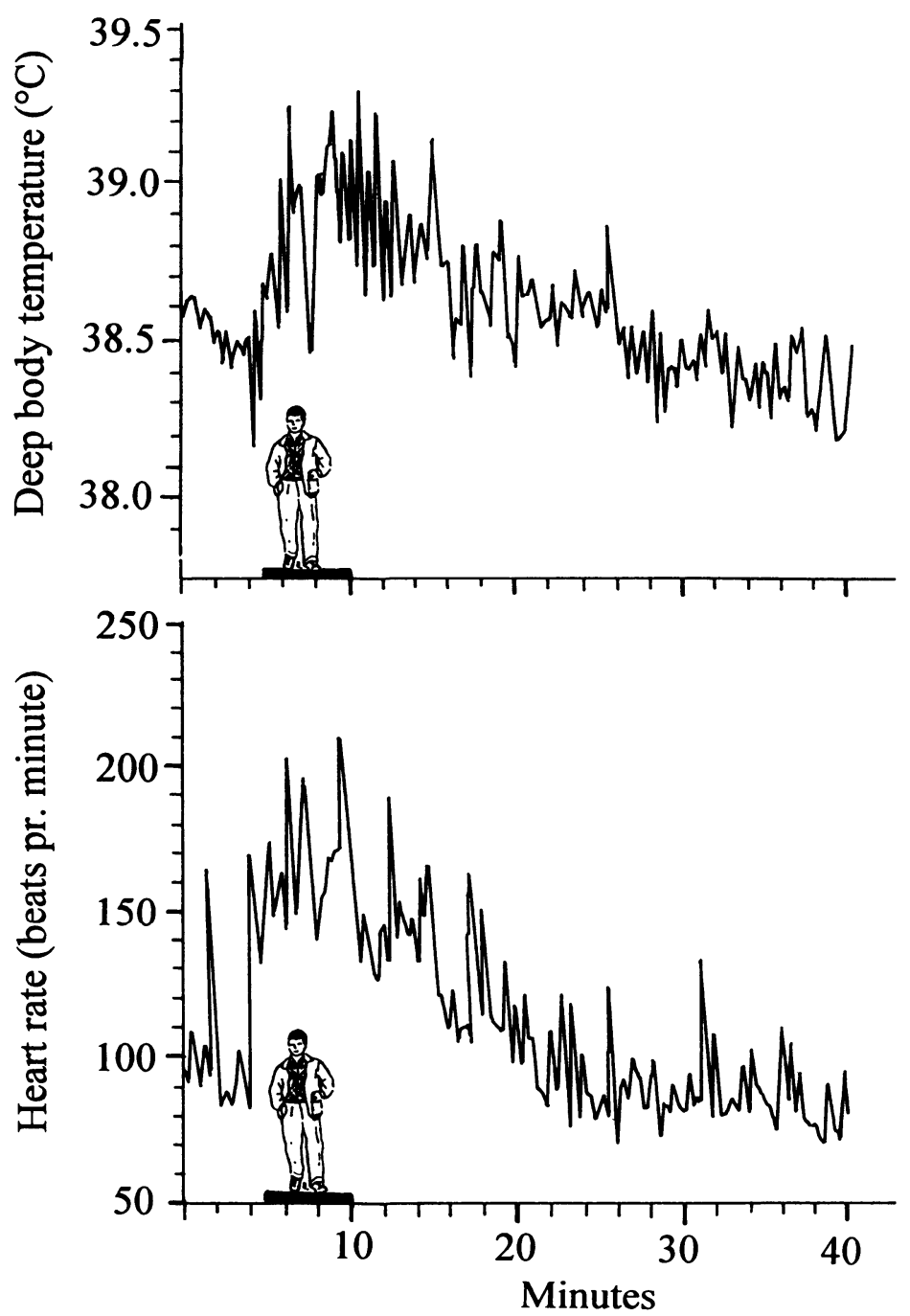

Figure 4. Observations of deep body temperature and heart rate in one silver fox during the presence of a person for $5 \mathrm{~min}$.

within the range of previous studies using a total counting method (Pedersen \& Jeppesen 1990). Thus, the observed leucocyte counts probably reflected true levels.

Glucose levels increased during handling and restraint. The initial glucose levels exceeded basal levels, which have been reported to be ap- proximately 6-7 mmol/1 in this species (Berestov 1989). The blood samples were drawn approximately $20 \mathrm{~h}$ after the foxes had been fed and were therefore considered not to reflect glucose contents of the food. It has been reported that hyperglycemia may be induced by circulating adrenaline released from the adrenal me- 

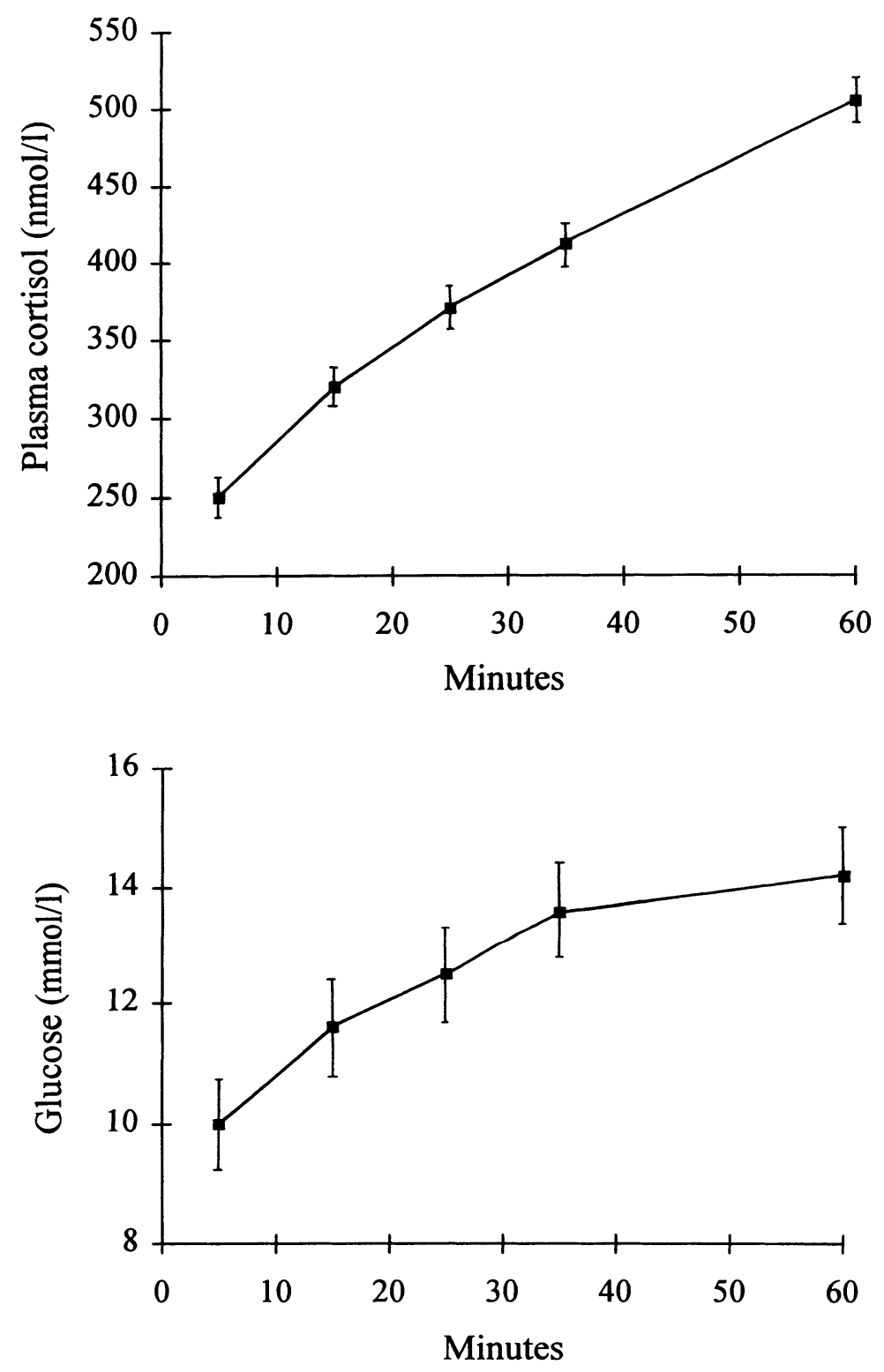

Figure 5. Mean plasma cortisol levels ( \pm SE) and mean plasma glucose levels $( \pm$ SE) in 6 silver foxes during one hour of physical restraint.

dulla (Smythe et al. 1989) and, thus, the elevated initial levels as well as the increase during restraint may indicate an activation of the SAM system. Increasing heart rate during the presence of a person supports this assumption. Similar to our results, glucose levels in mice, with 


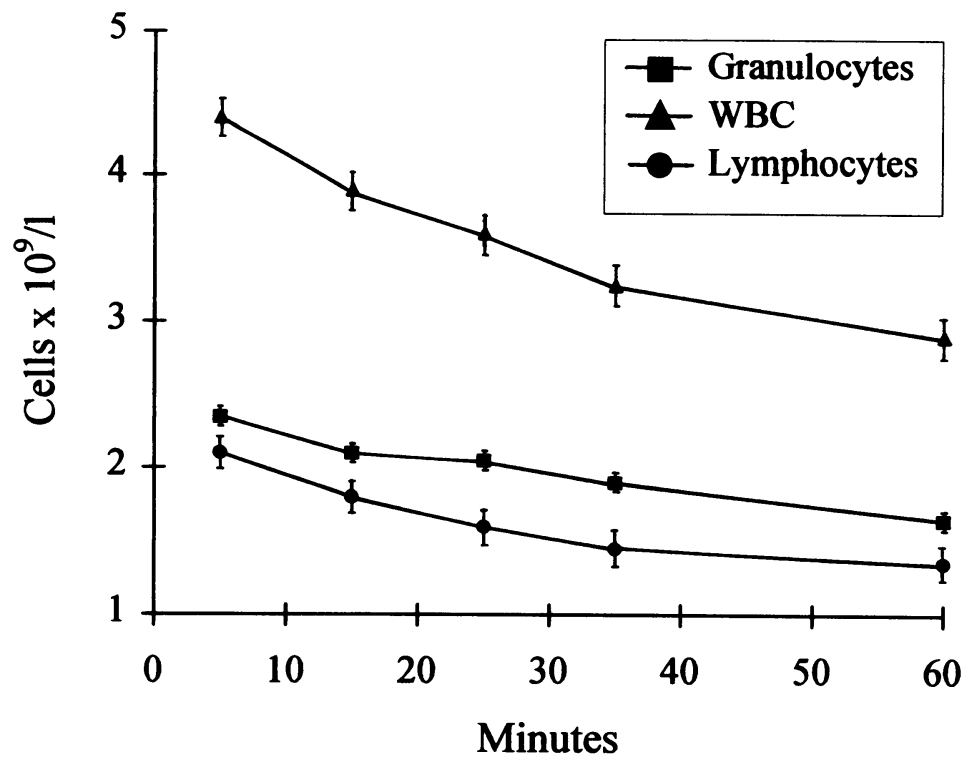

Figure 6. Mean leucocyte counts $( \pm \mathrm{SE})$ in 6 silver foxes during one hour of physical restraint. The time elapsed between capture and the first registration was approximately $5 \mathrm{~min}$, indicated by the open space between 0-5 $\mathrm{min}$.

initial levels of $11 \mathrm{mmol} / \mathrm{l}$, were significantly increased after $10 \mathrm{~min}$ and $30 \mathrm{~min}$ of handling for repeated rectal temperature measurement (Groenink et al. 1994).

Furthermore, as $\mathrm{T}_{\text {rec }}$ in restrained foxes differed from $T_{b}$, the question about the "normal" body temperature in farmed silver foxes arises. In most of our studies, $\mathrm{T}_{\text {rec }}$ immediately after capture was $39.4-39.7^{\circ} \mathrm{C}$, with extreme values from approximately 38.7 to $42^{\circ} \mathrm{C}$ (Moe \& Bakken, in press; Moe \& Bakken unpublished observations), whereas a "normal" body temperature in silver foxes has been reported to be 38.0-39.5 ${ }^{\circ} \mathrm{C}$ (Wenzel \& Berestov 1986). However, in agreement with our observations, Wenzel \& Berestov (1986) emphasized that stress strongly influences the temperature measured. In our preliminary studies, $\mathrm{T}_{\text {rec }}$ showed intertechnician differences, which may indicate that the stressfulness of capture and handling may depend on habituation to the handler. This phe- nomenon has also been noted in mice (Zethof et al. 1994). $\mathrm{T}_{\mathrm{b}}$ in undisturbed foxes of the present study ranged between $38.0-38.4^{\circ} \mathrm{C}$, which probably reflects a true base level. $\mathrm{T}_{\text {rec }}$ in the present study after approximately $5 \mathrm{~min}$ of physical restraint was of a similar magnitude as that in adult silver foxes with endotoxin-induced fever immediately after capture (Moe \& Bakken, in press). However, in a recent Polish study on infectious fox encephalitis in polar foxes (Alopex lagopus), $39-40^{\circ} \mathrm{C}$ was interpreted as a normal body temperature in this species even if these animals showed symptoms of disease (Kopczewski et al. 1996). Thus, the interpretation of body temperature in silver foxes when measured rectally may be difficult both in research and veterinary practice.

The immediate rise of $\mathrm{T}_{\text {rec }}$ in response to handling emphasizes the need for a remote data sampling technique if SIH is to be applied as an indicator of stress in welfare and behavioural 
research. However, as our previous studies showed that $T_{b}$ immediately started to increase during handling, and that this increase coincided with $T_{\text {rec }}, T_{\text {rec }}$ was considered to be as valid tool for the investigation of $\mathrm{SIH}$ as a phenomenon per se (Moe \& Bakken manuscript accepted; Moe unpublished observations). Furthermore, our results show that a valid interpretation of basal levels of the variables investigated in the present study may be obscured by handling routines. This cautious view concerning the use of blood parameters in stress research when sampling involves handling emphasizes the need for further reserach concerning remote sampling methods in this species.

In the light of the presented and discussed data, $\mathrm{SIH}$ in silver foxes was evoked simultaneously with an activation of the HPA axis and the SAM system within the first registration at $5 \mathrm{~min}$. The activation of these systems continued during one hour of physical restraint. These findings indicate a correlation between the $\mathrm{SIH}$, the SAM system and the HPA axis, which is in agreement with conclusions drawn from a previous study in mice (Groenink et al. 1994). If increases in body temperature during stress is measured with transmitter implants, SIH may be a promising "novel" tool to assess stress responses from unrestrained farmed silver foxes. Thus, the recognition of acute environmental stressors may be facilitated in studies where animal welfare is in focus. The practical application of SIH measured with transmitter implants during welfare studies is a subject of our further investigations.

\section{Acknowledgements}

We would like to thank Magnhild Fossberg and Arve Halstvedt at the Research Farm of the Agricultural University of Norway for their assistance during the experiment, and Grete Tuven for drawing the figures.

\section{References}

Anonymous: Dataquest III User Manual, Data Sciences, Inc., St. Paul, MN, USA, 1991.

Berestov VA: Carbohydrates. In: Brandt A. (ed.): Haematology and clinical chemistry of fur animals. Scientifur, Tjele, Denmark, 1989, pp 64-65.

Borsini F, Lecci A, Volterra G, Meli A: A model to measure anticipatory anxiety in mice? Psychopharmacol. 1989, 98, 207-211.

Briese E, Cabanac M: Stress hyperthermia: Physiological arguments that it is a fever. Physiol. Behav. 1991, 49, 1153-1157.

Cabanac A, Briese E: Handling elevates the colonic temperature of mice. Physiol. Behav. 1991, 51, 95-98.

Chrousos GP, Loriaux DL, Gold PW: The concept of stress and its historical development. In: Chrousos GP, Loriaux DL, Gold PW (eds.): Mechanisms of physical and emotional stress. Plenum Press, New York, 1988, pp. 3-7.

Groenink L, Gugten Jvan der, Zethof T, Heyden Jvan der, Olivier B: Stress-induced hyperthermia in mice: Hormonal correlates. Physiol. Behav. 1994, 56, 747-749.

Jeppesen LL, Pedersen V: Effects of whole-year nest boxes on cortisol, circulating leucocytes, exploration and agonistic behaviour in silver foxes. Behav. Proc. 1991, 25, 171-177.

Kluger MJ, O'Reilley B, Shope TR, Vander AJ: Further evidence that stress hyperthermia is a fever. Physiol. Behav. 1987, 39, 763-766.

Kopczewski A, Roszkowski J, Zdunkiewicz T, Strzalkowski L, Ulewicz $W$ : Infectios encephalitis in polar foxes. IFASA August 21-23, 1996, Warsaw, Poland, Applied Science reports 28, Progress in fur animal science, PL ISSN 1230-5367, pp. 215216.

Lecci A, Borsini F, Volterra G, Meli A: Pharmacological validation of a novel animal model of anticipatory anxiety in mice. Psychopharmacol. 1990, 101, 255-261.

Long NC, Vander AJ, Kluger MJ: Stress-induced rise of body temperature in rats is the same in warm and cool environments. Physiol. Behav. 1990a, 47, 773-775.

Long NC, Kunkel SL, Vander AJ, Kluger MJ: Antiserum against tumor necrosis factor increases stress hyperthermia in rats. Am. J. Physiol. 1990b, 258, R591-R595.

Madden KS, Felten DL: Experimental basis for neural-immune interactions. Physiol. Rev. 1995, 75, 77-106. 
Moberg GP: Biological response to stress: Key to assessment of animal well-being? In: Moberg, G. P. (ed.): Animal stress. Waverly Press Inc., Baltimore, Maryland 21202, USA, pp. 27-49, 1985.

Moe RO, Bakken M, Haga Ø, Smith A: Techniques for surgical implantation of radio transmitters in the silver fox (Vulpes vulpes). J. Zoo Wildl. Med. 1995, 26, 422-429.

Moe RO, Bakken M: Effect of repeated blood sampling on plasma concentrations of cortisol and testosterone and on leucocyte number in silver fox vixens (Vulpes vulpes). Acta. Agric. Scand. 1996, 46, 111-116.

Moe RO, Bakken M: Effect of indomethacin on LPSinduced fever and on hyperthermia induced by physical restraint in the silver fox (Vulpes vulpes). J. therm. Biol. In press.

Pedersen V, Jeppesen $L L$ : Effects of early handling on later behaviour and stress responses in the silver fox (Vulpes vulpes). Appl. Anim. Behav. Sci. 1990, 26, 383-393.

Pedersen V: Long-term effects of different handling procedures on behavioural, physiological, and production-related parameters in silver foxes. Appl. Anim. Behav. Sci. 1994, 40, 285-296.

Smythe GA, Pascoe WS, Storlien LH: Hypothalamic noradrenergic and sympathoadrenal control of glycemia after stress. Am. J. Physiol. 1989, 247, E765-E771.

SAS Institute Inc.: SAS User's Guide: Statistics, Version 6 Edition. Cary, NC., 1986.

Wenzel UD, Berestov VA: Pelztierkrankheiten (Fur animal diseases), VEB Deutscher Landwirtschafts-verlag DDR 1040 Berlin. 1986, pp. 31-43.

Zethof TJJ, van der Heyden JAM, Tolboom JTBM, Olivier B: Stress-induced hyperthermia in mice:
A methodological study. Physiol. Behav. 1994, $55,109-115$.

\section{Sammendrag}

Effekt av håndtering og fysisk immobilisering på rektaltemperatur, kortisol, glukose og antall leukocytter hos sølvrev (Vulpes vulpes).

Rektal temperatur, plasma kortisol, plasma glukose og antall leukocytter ble registrert hos 6 sølvrev tisper gjennom en times fysisk immobilisering. Dyp kroppstemperatur ble målt med implanterte radiosendere hos 6 andre sølvrever som ikke ble utsatt for håndtering, og hos en rev som ble utsatt for 5 minutters nærvær av mennesker. Rektal temperatur var markert høyere enn dyp kroppstemperatur, og økte under immobilisering. Dyp kroppstemperatur ved nærvær av menneske økte raskt samtidig med en $ø k n i n g$ av hjertefrekvens. Plasma kortisol og glukose økte mens antall leukocytter ble redusert i løpet av en times immobilisering. I lys av resultatene og tidligere observasjoner ble det konkludert at håndtering utløser en stressindusert hypertermi, og en aktivering av HPA aksen og SAM systemet sannsynligvis innen første registrering 5 minutter etter uttak fra buret. Denne aktiveringen fortsatte i løpet av en times fysisk immobilisering. Funnene viser at 'basal-nivåer' av de undersøkte parametrene kan influeres av håndteringsrutiner hos denne arten og derfor være problematisk å definere i forskning og i veterinær praksis. Hvis økning i kroppstemperatur måles med implanterte radiosendere kan effekten av ulike stressorer registreres uten å måtte håndtere dyrene. Metoden for å registrere stress-indusert hypertermi som et fysiologisk supplement til adferdsstudier der stress og velferd hos farmet sølvrev er i fokus er under videre utvikling.

(Received July 10, 1996; accepted October 15, 1996).

Reprints may be obtained from: R. Oppermann Moe, Norwegian College of Veterinary Medicine, Research Farm, Rustadveien 131, N-1380 Heggedal, Norway. Tel: +47 667970 34, fax: +47 66797410 . 
